Article

\title{
Corporate Social Responsibility, Organizational Justice and Positive Employee Attitudes: In the Context of Korean Employment Relations
}

\author{
Heung-Jun Jung ${ }^{1}$ (D) and Mohammad Ali ${ }^{2, *}$ \\ 1 Korea Labor Institute, 623 Sejong National Research Complex, Sicheong-daero, Sejong-si 30147, Korea; \\ hjunjung@kli.re.kr \\ 2 School of Business Administration, Penn State (Harrisburg), E335 Olmsted Building, \\ 777 West Harrisburg Pike, Middletown, PA 17057, USA \\ * Correspondence: maa31@psu.edu
}

Received: 2 August 2017; Accepted: 27 October 2017; Published: 31 October 2017

\begin{abstract}
In recent years, there has been a noticeable increase in scholarly interest in corporate social responsibility and its impact on employee attitudes. We intend to add to this literature by introducing unique explanatory and contextual variables. The study explains the impact of Corporate Social Responsibility (CSR) on employee attitudes through justice within the context of cooperative employee relations. We argue that the concept of justice, which is implied in both socially responsible organizational policies and cooperative employee-employer relations, may be an important addition as a mediating variable. In essence, the study explores the mediating effects of the two primary types of justice, i.e., distributive and procedural, on the relationship between perceived corporate social responsibility, and job satisfaction, and affective commitment. Additionally, we introduce ethics-based psychological foundations, i.e., heuristic and deontic fairness theories to explain the studied relationship. The study also examines the moderated mediation effects of the cooperative industrial relations climate on perceived corporate social responsibility and justice perceptions. Our analysis supports the mediating role of both distributive and procedural justice perceptions. However, a moderated mediation role of the industrial relations climate was only found in the relationship between perceived corporate social responsibility, procedural justice, and employee attitudes. Implications of the study are discussed.
\end{abstract}

Keywords: corporate social responsibility; sustainable management practices; organizational justice; affective commitment; job satisfaction

\section{Introduction}

In recent years, various studies have demonstrated a direct positive relationship between employee CSR perception and positive employee attitudes [1-6]. We agree that CSR perception is an important variable that affects employee attitudes. However, we argue there may be some explanatory and contextual variables that may collectively provide a thorough and integrated understanding of the impact of CSR on employee attitudes. Hence, we propose mediating roles of distributive and procedural justice between CSR perception and job satisfaction and affective organizational commitment. Furthermore, we explore the moderating influence of cooperative industrial relations (IR) on the stated relationships.

In subsequent sections, we will discuss and illustrate the relevant existing academic literature, the observed gaps in that research, and our intended contribution. However, suffice here to say that we intend to make two singular contributions to the literature on CSR perception and its impact on employee attitudes. 
First, we attempt to pay the deserved homage to the concept of justice in the relationship between CSR perception and job satisfaction and affective organizational commitment. We argue that CSR and justice share a similar tripartite structure of human needs, i.e., instrumental, relational, and ethics-based [7]. Hence, it would be useful to understand how these two different organizational policies with similar psychological underpinnings interact with each other. We achieve our tribute to justice in two ways. First, we explain the relationship between CSR and employee attitudes by testing new explanatory variables, i.e., distributive and procedural justice, as mediators, and suggest a full mediation model. Additionally, we propose unique psychological mechanisms, i.e., heuristic and deontic fairness, to explain the impact of CSR on job satisfaction and affective organizational commitment. Second, most studies utilize social identity theory (SIT) and social exchange theory (SET) as psychological mechanisms to explain the impact of CSR on employee attitudes and behavior [7]. We argue that SIT and SET satisfy the instrumental and relational psychological foundations of the relationship between CSR and employee attitudes, whereas, heuristic and deontic fairness theories represent non-egocentric cognitive processes that embody the principles of fair treatment of all human beings. Hence, they offer an ethics-based mechanism to explain the impact of CSR on employee attitudes [8].

Second, we argue that the proposed relationships in our model will be further strengthened if the organizational context is based on the underlying principles of fairness [9]. Hence, we consider a contextual factor, i.e., cooperative industrial relations (IR) climate in a unionized setting, and suggest a moderated mediation role of a cooperative IR climate in the studied relationships. In recent years, cooperative IR systems have proliferated in most developed nations in union and non-union settings. We argue that these IR systems signify management practices that focus on egalitarian workplace environments with empowerment, autonomy, inclusive decision-making, and trust [10]. Therefore, a cooperative IR climate may reinforce the employee perception, in a union setting, of organizational CSR and fairness.

Finally, we achieve the objectives of our study by conducting our research in the Korean industrial relations context. We discuss the Korean context in the following section. However, it is pertinent to add here that Korea provides our study with an appropriate context where the Korean government is actively promoting both cooperative employment relations and social responsibility. Additionally, our studied firm, Hyundai Motor Company, has over the years, due to particular institutional and business needs, improved its cooperative IR and CSR profile.

The paper begins with a discussion of the context of the study, i.e., employment relations and social responsibility in Korea in general and Hyundai Motor Company in particular. This discussion highlights certain contextual factors that help explain our results. Then we present our hypotheses and comprehensively discuss pertinent literature. The subsequent sections outline the methodology, results, and implications of our findings.

\section{Context of the Study}

\subsection{Cooperative Industrial Relations Climate and Social Responsibility in Korea}

Kong [11] argues that Korean employment relations are affected by three legacies of late industrialization: rapid industrialization between the 1960s and the 1980s achieved through state planning; the rise of the government-promoted conglomerate system, i.e., Chaebol system, that weakened the direct control of employment relations by the Korean state and increased autocratic control of the leading industrial houses; and successful industrialization combined with domination of an autocratic and repressive Chaebol system, creating the environment for a hostile and militant labor movement. This movement gained further support during the political democratization of Korea in 1987, when an era of confrontational employment relations was ushered in. Korea, unlike most industrial nations, did not enjoy an extended period of employment stability; this instability had an overall negative effect on industrial relations. These factors, combined with the 1997 financial crisis, increased the labor-management difficulties and antagonism in the late 1980s and the 1990s. 
Heightened industrial antagonism created the need for the Korean government to support cooperative employment relations practices [12]. Essential ingredients in this strategy were the promotion of Labor Management Councils (LMC) and high-performance work systems (HPWS) $[13,14]$. Although created in 1963, LMCs only became a substantive part of the Korean employment relations system in 1996 with the Promotion of Worker Participation and Co-operation act. The act aimed at improving worker participation rights and gave LMCs legal, independent, and autonomous status [15]. As a result of this act, LMCs started to function more effectively, enhancing labor-management cooperation and providing both parties with a useful forum to address issues of mutual concern [16].

To improve labor-management relations at the shop floor level and promote competitiveness through innovation and collaboration, institutional support for HPWS was provided by the Korean government [11,14]. Several steps were taken to achieve this support: in 1997, the government provided financial assistance to companies that adopted labor-management partnership arrangements; in 1999, policy guidelines were established stressing practices that encouraged greater communication and information sharing [14]; and, in 2009, a Korea High-Performance Workplace Innovation center was created, in which expert and specialized consulting on HPWS was offered. These efforts resulted in the proliferation of several HPWS practices in the Korean workplace [17].

In recent decades, CSR has also become an important part of the Korean corporate agenda. This trend is evident from the increase in CSR expenditure of the top 220 Korean firms from \$1.9 billion USD in 2008 to $\$ 2.5$ billion USD in 2010 [18]. Both Korean history and culture and institutional pressures have influenced this trend. Because their culture is based on Confucianism, Koreans emphasize collectivism, harmony, and cohesion [19]. The government, which considers social responsibility expenditure as a quasi-tax or job creation mechanism, also puts pressure on Korean firms to be socially responsible [20]. Finally, to operate in international markets, Korean corporations have followed the global trend towards CSR and have complied with international standards emanating from several different sources [20].

\subsection{IR Climate and CSR at Hyundai Motor Company (HMC)}

In 1968, HMC was an assembler for Ford Motor Company. It launched its first original car design in 1976 [21]. HMC was initially part of the Hyundai business group, which is one of the oldest and most successful Chaebols in Korea [22]. As HMC grew, it was separated from Hyundai to curtail the power and influence of the conglomerate [21]. HMC is now a multinational company with operations in 13 countries with close to 100,000 employees [23].

Over the years, in accordance with the overall evolution of employment relations in Korea, employment relations practices in HMC have become less paternalistic and more inclusive and cooperative. In its formative years, the HMC HR policies focused on: a dual labor market strategy by differentiating between managers and employees on: selection criteria and benefits; a seniority system of promotion; and paternalistic management practices [24]. Like companies in all other industrial sectors in Korea, HMC's paternalistic and suppressive policies led to worker dissatisfaction and strikes. Thus, HMC has a long history of adversarial relations with one of the most well-organized and militant unions in Korea: the Korean Confederation of Trade Union [25,26].

Union militancy and industrial strife made HMC realize the importance of labor-management cooperation. To resolve its problems, HMC started to negotiate with unions over wages and working conditions, and a collective bargaining agreement was reached in 2000 [26]. In addition, an extensive welfare system was implemented, training was increased, and cultural programs were offered [21]. Finally, the company established a broad range of HR policies to promote convergence of interests between employees and management. As a result, union members became part of project teams, joining with management to oversee the new welfare programs. Wages increased by $20 \%$ in $1987,30 \%$ in 1988, and 28\% in 1989, compared with 6\% between 1982 and 1986, and union members received similar benefits from welfare systems to those of managers [21].

In addition to achieving cooperative employment relations, HMC has also improved and promoted its CSR profile. HMCs journey towards social responsibility effectively started in 2001 when 
its Ethics Charter and Employee Code of Conduct was established. From 2002 to 2007, the company implemented a voluntary Fair Trade Compliance program, published guidelines for ethical business conduct, and established an Ethics Committee within the Board of Directors. Since 2008, HMC has joined the Global Compact, signed a Fair Trade Agreement with its suppliers (Phases I, II, and III), established new accounting standards, and promoted its Voluntary Fair Trade Compliance program. In 2012, HMC spent close to $\$ 70$ million USD in expenses related to social projects, and 31,862 of its employees freely volunteered for community involvement and service programs [23].

Finally, HMC has published comprehensive sustainability reports since 2003. The 2013 sustainability report met the parameters of the G3.1 Global Reporting Initiative guidelines, and the data were collected and organized under ISO 26000 standards. To improve the validity of its reports, HMC gets its data verified annually by outside experts in accordance with the ISO 14001 certification procedures.

The 2013 report illustrates the companys core management philosophy that focuses on a multistakeholder approach to business and revolves around three key ideas: a sense of unlimited responsibility (signifying stakeholder responsibilities and sustainable growth), the realization of possibilities (signifying imaginative ideas and innovation), and love for humanity (signifying the contribution of humanity). Based on these management principles, HMC's report is divided into sections that elucidate a stakeholder approach to management and illustrate steps that HMC has taken to create collaborative relationships with different stakeholders.

\section{Literature Review and Hypotheses}

\subsection{Organizational CSR and Employees Attitudes}

We follow the broad definition of CSR as propounded by Carroll [27,28]. Carroll [27] emphasizes four types of organizational responsibilities: economic, legal, ethical, and philanthropic. These four categories are neither mutually exclusive nor on a continuum; they can co-exist and represent classifications of organizational actions and motives [27]. Furthermore, these four responsibilities are not to be fulfilled sequentially, but all must be realized concomitantly [29]. Most importantly, these CSR domains underscore the idea that organizations seek to attain social as well as traditional economic benefits by creating congruence between societal expectations, ethical business standards, and business needs [30,31].

In the last two decades, findings of several studies (including some meta-analyses) suggest somewhat of a consensus that there is a positive relationship between social responsibility and firm-level performance [32-36]. It has also been found that perceptions regarding organizational CSR not only help attract good employees [37,38], but they also have a positive effect on employee work-related attitudes, emotions, and behaviors [1-3,6,39-42].

Pertinent to our study, there has also been considerable scholarly work on the psychological mechanisms, i.e., mediators, moderators, and contextual factors underlying the relationship between CSR perception and positive employee attitudes (Table 1). A closer look at this literature reveals that most of the studies look at individual psychological mediating variables (e.g., ideological needs, organizational support, meaningfulness, organizational identity, organizational trust, organizational pride, and organizational citizenship behavior). Some studies include organizational level variables or attempt to establish a link between individual and organizational variables (e.g., organizational prestige (external), and congruence between employee-employer CSR orientations). Regarding moderators, studies have focused on an array of individual (e.g., CSR proximity perceived overall justice, calling orientation, type of employees, and socio-economic consciousness), organizational (e.g., organizational social accounts), and institutional (e.g., cultural dimensions) variables. 
Table 1. Selected Studies on impact Corporate Social Responsibility (CSR) Perception on Employee Behaviors.

\begin{tabular}{|c|c|c|c|c|c|}
\hline \multirow{2}{*}{ Authors } & \multirow{2}{*}{ Type of Study } & \multicolumn{4}{|c|}{ Variables } \\
\hline & & IV & DV & Mediators & Moderators \\
\hline $\begin{array}{l}\text { Haski-Leventhal } \\
\text { et al. [43] }\end{array}$ & $\begin{array}{c}\text { Theoretical Model } \\
\text { with a short } \\
\text { Case Study }\end{array}$ & CSR Efforts & $\begin{array}{l}\text { Outcomes for } \\
\text { employees }\end{array}$ & $\begin{array}{c}\text { Congruence and } \\
\text { non-congruence of } \\
\text { Employer-employee } \\
\text { Social Responsibility }\end{array}$ & - \\
\hline $\begin{array}{l}\text { Fryzel and } \\
\text { Seppala [45] }\end{array}$ & $\begin{array}{l}\text { Empirical Study } \\
\text { (Quantitative) }\end{array}$ & $\begin{array}{l}\text { Identity } \\
\text { Orientation }\end{array}$ & $\begin{array}{c}\text { Affective } \\
\text { Attachment to CSR }\end{array}$ & $\begin{array}{l}\text { Evaluation of CSR } \\
\text { Motives }\end{array}$ & - \\
\hline $\begin{array}{l}\text { De Roeck and } \\
\text { Maon [46] }\end{array}$ & Theoretical Model & $\begin{array}{l}\text { The authors draw o } \\
\text { psychological me }\end{array}$ & $\begin{array}{l}\text { Social Identity Theo } \\
\text { chanisms that explair } \\
\text { outcomes, and org }\end{array}$ & $\begin{array}{l}\text { y and Social Exchange } \\
\text { the relationship betwee } \\
\text { nizational outcomes. }\end{array}$ & $\begin{array}{l}\text { heory to outline the } \\
\text { a CSR, employee }\end{array}$ \\
\hline $\begin{array}{l}\text { De Jong and Van } \\
\text { der Meer [48] }\end{array}$ & $\begin{array}{l}\text { Empirical Study } \\
\text { (Qualitative } \\
\text { Content Analysis) }\end{array}$ & \multicolumn{4}{|c|}{$\begin{array}{l}\text { The authors take up the question of congruence between } \\
\text { Organizations and their CSR activities }\end{array}$} \\
\hline Du et al. [49] & $\begin{array}{l}\text { Empirical Study } \\
\text { (Quantitative) }\end{array}$ & CSR Initiatives & $\begin{array}{l}\text { Job Satisfaction } \\
\text { and Turnover } \\
\text { Intention }\end{array}$ & $\begin{array}{l}\text { Developmental } \\
\text { Needs Fulfillment } \\
\text { and Ideological } \\
\text { Needs Fulfillment }\end{array}$ & CSR Proximity \\
\hline Slack et al. [50] & $\begin{array}{c}\text { Empirical Study } \\
\text { (Qualitative } \\
\text { Case Study) }\end{array}$ & \multicolumn{4}{|c|}{$\begin{array}{l}\text { An exploratory case study that looks at employee engagement with CSR and the } \\
\text { impediments related to this engagement. }\end{array}$} \\
\hline Farooq et al. [53] & Quantitative Study & CSR & $\begin{array}{l}\text { Organizational } \\
\text { Commitment }\end{array}$ & $\begin{array}{c}\text { Organizational Trust } \\
\text { and Organizational } \\
\text { Identification }\end{array}$ & - \\
\hline $\begin{array}{l}\text { De Roeck } \\
\text { et al. [54] }\end{array}$ & Quantitative Study & Perceived CSR & Job Satisfaction & $\begin{array}{l}\text { Overall Justice and } \\
\text { Organizational } \\
\text { Identification }\end{array}$ & - \\
\hline Lee et al. [55] & $\begin{array}{l}\text { Empirical Study } \\
\text { (Quantitative) }\end{array}$ & $\begin{array}{c}\text { Corporate Culture } \\
\text { and CSR Activities } \\
\text { and Perceived CSR } \\
\text { Capability }\end{array}$ & $\begin{array}{c}\text { Employee } \\
\text { attachment, and } \\
\text { Perceived } \\
\text { Corporate } \\
\text { Performance }\end{array}$ & $\begin{array}{c}\text { Employee perception } \\
\text { of CSR activities }\end{array}$ & - \\
\hline $\begin{array}{l}\text { Glavas and } \\
\text { Godwin [56] }\end{array}$ & Theoretical Model & $\begin{array}{l}\text { Perceived External } \\
\text { Image of CSR and } \\
\text { Perceived Internal } \\
\text { Image of CSR }\end{array}$ & $\begin{array}{c}\text { Employee } \\
\text { Organizational } \\
\text { Identification }\end{array}$ & $\begin{array}{l}\text { Salience of CSR to } \\
\text { Employee }\end{array}$ & - \\
\hline You et al. [57] & Quantitative Study & CSR Investment & $\begin{array}{c}\text { Job Satisfaction } \\
\text { and Organizational } \\
\text { Commitment }\end{array}$ & $\begin{array}{l}\text { Organizational } \\
\text { Commitment } \\
\text { through Job } \\
\text { Satisfaction }\end{array}$ & - \\
\hline $\begin{array}{l}\text { McShane and } \\
\text { Cunningham [58] }\end{array}$ & $\begin{array}{l}\text { Empirical Study } \\
\text { (Qualitative } \\
\text { Interview Based) }\end{array}$ & $\begin{array}{r}\text { The research wa } \\
\text { Inauthentic organiza } \\
\text { of tl }\end{array}$ & $\begin{array}{l}\text { looking at how empl } \\
\text { ional CSR programs. } \\
\text { e firm. The study finc } \\
\text { leads to organiza }\end{array}$ & $\begin{array}{l}\text { yees distinguish betwe } \\
\text { How this judgment influ } \\
\text { s that Perceived authen } \\
\text { ional identification. }\end{array}$ & $\begin{array}{l}\text { n Authentic and } \\
\text { nces their perception } \\
\text { icity }\end{array}$ \\
\hline
\end{tabular}


Table 1. Cont.

\begin{tabular}{|c|c|c|c|c|c|}
\hline \multirow{2}{*}{ Authors } & \multirow{2}{*}{ Type of Study } & \multicolumn{4}{|c|}{ Variables } \\
\hline & & IV & DV & Mediators & Moderators \\
\hline Mueller et al. [59] & Empirical Study & $\begin{array}{l}\text { Employee } \\
\text { Perception of } \\
\text { Organizational } \\
\text { Responsibility }\end{array}$ & $\begin{array}{l}\text { Affective } \\
\text { Organizational } \\
\text { Commitment }\end{array}$ & - & $\begin{array}{l}\text { Global Leadership } \\
\text { and Organizational } \\
\text { Behavior } \\
\text { Effectiveness } \\
\text { (GLOBE) }\end{array}$ \\
\hline $\begin{array}{l}\text { Bauman and } \\
\text { Skitka [60] }\end{array}$ & Theoretical Study & \multicolumn{4}{|c|}{$\begin{array}{l}\text { This theoretical paper identifies four paths through which CSR may affect employees } \\
\text { based on four psychological needs, i.e., security, self-esteem, belongingness, } \\
\text { and meaningful existence. The study, in essence, provides us with psychological } \\
\text { underpinnings of the relationship between CSR and employee attitudes. }\end{array}$} \\
\hline $\begin{array}{l}\text { De Roeck and } \\
\text { Delobbe [61] }\end{array}$ & $\begin{array}{l}\text { Empirical Study } \\
\text { (Quantitative) }\end{array}$ & $\begin{array}{c}\text { CSR } \\
\text { (Environmental) }\end{array}$ & $\begin{array}{l}\text { Organizational } \\
\text { Identification }\end{array}$ & Organizational Trust & - \\
\hline Hansen et al. [62] & Quantitative Study & Perceived CSR & $\begin{array}{l}\text { Organizational } \\
\text { Citizenship } \\
\text { Behavior }\end{array}$ & Organizational Trust & - \\
\hline $\begin{array}{l}\text { Herrbach and } \\
\text { Mignonac [63] }\end{array}$ & $\begin{array}{l}\text { Empirical Study } \\
\text { (Quantitative) }\end{array}$ & $\begin{array}{c}\text { Perceived External } \\
\text { Prestige }\end{array}$ & $\begin{array}{c}\text { Job Satisfaction, } \\
\text { Affective } \\
\text { Organizational } \\
\text { Commitment, and } \\
\text { Affective Wellbeing } \\
\text { at Work }\end{array}$ & - & Type of Employee \\
\hline Rupp et al. [39] & Theoretical Study & Perceptions of CSR & $\begin{array}{l}\text { Employee } \\
\text { Emotions, } \\
\text { Attitudes, and } \\
\text { Behaviors }\end{array}$ & $\begin{array}{l}\text { Instrumental, } \\
\text { Relational, and } \\
\text { Deontic } \\
\text { Motives/needs }\end{array}$ & $\begin{array}{l}\text { Organizations' } \\
\text { Social Accounts }\end{array}$ \\
\hline
\end{tabular}

The scholarly contributions on the relationship between CSR and employee attitudes are no doubt considerable. However, we intend to add to this literature by making three assertions: (1) justice is an important variable in the relationship between CSR and employee attitudes; (2) there is a need to stress on ethics-based cognitive processes to elucidate the relationship between CSR and employee attitudes; and (3) a supportive organizational milieu is important and may reinforce the relationship between CSR and employee attitudes. The third assertion will be discussed later, let us now delve a little more in-depth in the first two.

We argue that the psychological underpinnings of the impact of employee perception of organizational CSR and justice on employee behaviors and attitudes are predicated on the fulfillment of three commonly experienced intrinsic employee needs, i.e., self-interested or instrumental [64]; relational [65]; and norms of justice and ethics [7,8]. Therefore, justice and CSR though two different concepts representing different organizational policies and structure share common psychological assumptions $[39,66]$. We argue that we may get a more integrated and comprehensive understanding of the impact of CSR on employee attitudes if we explain this relationship through justice.

Before we explore our second claim it is pertinent to discuss, in some detail, the mentioned shared cognitive foundations of CSR and justice. Instrumental needs focus on economic or quasi-economic personal goals and may signify the desire for greater control over the achievement of one's goals $[7,8,67]$. The relational or interpersonal needs signify the standing of the individual within a valued group where injustice might indicate exclusion from the group or diminished value in the group [7]. The ethics-based needs denote that employees may "care about fairness due to what seems to be an evolutionary based, universally held moral norm of justice" [7]. In essence, the first two needs are egocentric and may ignore principles of moral justice that may include employee response to fair treatment of others by the firm. The ethics-based need, on the other hand, represents a different cognitive process that may consist of deontological judgments based on principles derived from moral ideas of respect for human beings, human dignity, and fair treatment $[8,68]$. Additionally, the desire for fair treatment of others may suggest that employees will not only react to injustice when it is done to them, but they will also react negatively to organizational injustice to others $[7,69,70]$. 
We predicate our second claim on the argument that the individual need for CSR and justice cannot be fully understood without discerning moral or ethical motives [8]. Most studies have relied on SIT to explain the direct link between CSR and employee attitudes [2,41,42,54]. Recently, however, Farooq et al. [53] have introduced SET as another mechanism to predict the relationship between CSR initiatives and employee attitudes. We argue that SIT and SET only invoke the instrumental and relational cognitive explanations of the relationship between CSR perception and positive employee attitudes [8,53], whereas, fairness heuristic and deontic theories embody the underlying ethical imperatives of fair treatment and represent the ethics-based core of CSR and justice. Let us now explore this argument in detail.

The danger in social interactions is that there is always a chance that the other party will engage in opportunistic behavior. Individuals in social interactions with social entities suffer diminished capacity to control the outcomes of the interaction as social entities usually wield higher levels of power, resources, and knowledge [67]. In an organizational context, this translates into an individual agreement to be vulnerable on some level while dealing with the firm. In such situations, individuals are more likely to trust the organization when there are strong indications that they will be treated fairly [67]. Fairness heuristic theory postulates that a significant exchange can be facilitated if individuals can evaluate with some level of confidence the overall fairness proclivities of the interacting social entity through readily available information on the entity [67]. In other words, employees may consider knowledge about their organization's corporate policy of social responsibility and socially responsible acts as a heuristic device to assess organizational propensity towards treating all stakeholders reasonably $[46,67]$. These evaluations once instituted may be considered by employees as implicit promises with moral imperatives [4,71], where the fulfillment of these promises may obligate the employees to reciprocate in kind [72]. In sum, a comprehensive organizational CSR profile that establishes the firm's inclination towards treating its myriad stakeholders fairly may develop an employee perception of overall organizational fairness and may compel the employees to reciprocate through positive workplace attitudes $[39,52]$.

Deontic fairness theory suggests that in the organizational context, the perception of justice may mostly be based on self-interest, but could also transcend self-interest and be driven by a broader universal idea of fairness $[8,41]$. This idea of fairness suggests that, "people innately possess moral duties to treat others fairly and that when people see others violate these duties by treating others unfairly, they will react, at least to a degree, as if they were the ones being treated unfairly" [62] (p. 31). Scholars have suggested that while employees do care about how organizations treat them, they are also influenced by how organizations treat other stakeholders, even to the point of resisting organizational unfairness at some personal cost [8]. In essence, from the deontic viewpoint, norms of fairness are universal, and individuals may hold organizations responsible and accountable for their behavior standards and their role in dispensing social justice to external individuals and societal groups $[39,67,73]$. Therefore, if employees perceive that their organization is being socially responsible and treating all its stakeholders fairly, then they may exhibit positive workplace attitudes [39].

In sum, we argue that fairness heuristic theory adds to the social exchange mechanism by suggesting that indication of fairness towards all stakeholders can be an antecedent to an equitable exchange relationship, while, fairness deontic theory represents a cognitive mechanism in which employees judge organizations based on how the organization dispenses justice to its external stakeholders [47]. Collectively, the fairness heuristic and deontic theories represent the ethics-based imperatives of fair treatment that are predicated on the norms of respect of human dignity.

\subsection{CSR on Distributive and Procedural Justice}

Corporate social responsibility and the concept of justice share the instrumental, relational, and ethics-based desire for normative treatment [39]. Organizational justice signifies standards of how employees are treated while CSR signifies organizational norms of treatment of employees and other external stakeholders [39]. Employees may evaluate organizational CSR and subsequently establish their perceptions of organizational justice [6]. Additionally, based on the foundational similarities 
between CSR and justice, it would not be too presumptive to argue that a positive increase in one might lead to an increase in the other.

We now clarify the relationship between the two primary types of justice, i.e., distributive and procedural [74] and CSR. In organizational terms, distributive justice refers to the employee-perceived fairness of outcomes (ends) and distribution of organizational resources [67]. On the other hand, procedural justice refers to the perceived fairness of the process (means) used to determine organizational outcomes [75]. Additionally, distributive justice is related to the assessment of specific individual outcomes, and procedural justice is related more to the evaluation of the systemic and institutional features [74].

Despite their distinctive meanings, both distributive and procedural justice may be affected by employee perceptions of organizational CSR and both may be explained by similar cognitive theories, i.e., heuristic and deontic fairness. Socially responsible organizational corporate strategy and related fair and consistent organizational processes are usually manifested through annual reports, CSR reporting, and codes of conduct. These revealed organizational tendencies may create a perception in employees that the firm will be fair with respect to their expected personal outcomes through established, reliable, and unbiased mechanisms, i.e., distributive and procedural justice, respectively. Additionally, employee perceptions of organizational distributive and procedural justice may also be positively motivated when their innate desire for third-party justice is satisfied by observing that their organization indulges in the concept of morality and dispenses due share to organizational stakeholders through established and impartial procedures.

Finally, in the context section, we have discussed the actions taken by HMC to improve its CSR profile. HMC has in the last fifteen years or so created codes of conduct, joined global organizations to be a part of the global discussion on the promotion of socially responsible behavior, signed Fair Tarde Agreement, has established adequate procedures, and has reported its efforts to its many constituents. Hence, it can be argued that after observing HMC's socially responsible policy, acts, and efforts its employees may have received adequate signals of HMC's socially responsible tendencies and may also have adequately satisfied their ethics-based needs leading to approbation and the development of a positive view of HMC's distributive and procedural justice.

Based on these ideas, the following hypotheses are presented:

Hypothesis 1. Perceptions of CSR and distributive justice are positively related.

Hypothesis 2. Perceptions of CSR and procedural justice are positively related.

3.3. The Mediating Role of Distributive and Procedural Justice in the Relationship between CSR, and Affective Organizational Commitment, and Job Satisfaction

The importance of justice lies in the fact that justice maintains an underlying emphasis on the satisfaction of vital individual psychological needs related to self-esteem, meaningful existence, belongingness, and respect as a valued organizational member [67]. Hence, scholars have established the relationship between organizational justice and employee outcomes. Colquitt et al. [76], in a meta-analytic review of 183 studies, show that both distributive and procedural types of justice are highly correlated with several organizational outcomes, including job satisfaction and affective commitment. Scholars have also found that employee work attitudes and behaviors are positively influenced by their perception of organizational fairness $[4,7,67]$, and perceived injustice is often considered a moral transgression to which employees have an adverse reaction [7].

Justice is important for employees, but there has been some academic debate over the relative importance of distributive versus procedural justice for certain types of employee outcomes. As previously discussed, distributive justice exists when employees perceive a congruence between their efforts and outcomes. Procedural justice, on the other hand, refers to the means by which fair distribution of resources has been achieved. Scholars have argued and found that distributive justice 
may contribute more than procedural justice to personal employee outcomes like job satisfaction [76]. On the other hand, scholars have argued and found that procedural fairness may be a better predictor of employee satisfaction with institutions and their representatives and may account more for organizational commitment than distributive justice [75,77]. However, others have also found that procedural justice may predict job satisfaction [76] and that distributive justice may predict organizational commitment [78].

This debate, though not the primary focus of our paper, is critical, as we argue that both distributive justice and procedural justice affect job satisfaction and affective organizational commitment. We base our argument on the ground that job satisfaction and organizational affective commitment are multifaceted, multilayered, general employee responses; hence, both may be affected by distributive and procedural justice [77].

As a broad, multifaceted employee response, job satisfaction may include several internal and external aspects of the job and may be predicted by both personal and institutional aspects of organizational life. Distributive justice may lead to job satisfaction as employees may expect a fair distribution of resources [79] and a fair chance at achieving their instrumental goals. On the other hand, procedural justice may also independently predict job satisfaction when individuals value fair procedures within the workplace [80] that convey respect of the organization towards individual employees [79]. This communication of respect confirms and guarantees employee importance in the organization, thus fulfilling their relational needs and improving their self-worth and eventually job satisfaction.

Affective organizational commitment to an organization refers to "the extent to which a business unit's employees are fond of the organization, see their future tied to that of the organization and are willing to make personal sacrifices for the business unit" [81]. This definition brings out the affective aspect of organizational commitment that indicates to a deeper affiliation between the employee and the organization by linking at least a part of individual identity with the organization [63]. We argue that affective organizational commitment is, like job satisfaction, a multilayered concept that can be affected by both personal and institutional variables [63]. Based on the norms of reciprocity, which are the basis of all meaningful social exchanges [82] employee perceptions of distributive justice may set a pattern in which employees may increase their investment in the company, demonstrating positive workplace attitudes, and high organizational affective commitment [83]. Additionally, procedural justice may affect organizational affective commitment when employees develop trust in the overall fairness of the procedures of the firm [77].

In line with the preceding discussion, we propose the following hypotheses:

Hypothesis 3. Distributive justice is positively related to: (a) affective organizational commitment; and (b) job satisfaction.

Hypothesis 4. Procedural justice is positively related to: (a) organizational affective organizational commitment; and (b) job satisfaction.

Given our discussion in the preceding two sections, we argue that the relationships among CSR perceptions, employee job satisfaction, and organizational affective commitment are mediated by distributive justice and procedural justice. Therefore, we hypothesize that:

Hypothesis 5. The relationship between perceptions of CSR and affective organizational commitment will be mediated by both distributive and procedural justice.

Hypothesis 6. The relationship between perceptions of CSR and job satisfaction will be mediated by both distributive and procedural justice. 


\subsection{The Moderated Mediated Effects of IR Climate}

Perceptions of management's fairness and trustworthiness often rely on environmental contexts that represent embedded organizational values [73]. We argue that contingent factors impacting the relationship between CSR and positive employee attitudes have been ignored in existing research [73]. More importantly, the nature of the employee-employer relationship has not yet been adequately discussed in the discourse of CSR and its impact on employees. Therefore, we introduce IR climate as a contextual variable and argue that employee perceptions of a cooperative and collaborative union-management relationship will strengthen the relationship between employee perceptions of CSR, organizational justice, and affective organizational commitment and job satisfaction.

In addition to the presented assertion, we justify our choice of cooperative IR climate as a moderator based on three arguments. First, in response to the increasing global competition, most developed countries have widely experimented with labor management cooperation in both union and non-union settings [84,85]. Hence, the high prevalence of cooperative IR necessitates, from a managerial point of view, to assess how they may interact with other organizational policies. Second, we argue that there may be similarities between the expected employee outcomes from cooperative IR, enumerated later, and organizational CSR and justice. Therefore, it could be of great managerial value if we can ascertain how these three different policies may interact to produce desirable employee results. Third, trade unions often consider organizational CSR activities as a threat because they believe that CSR policies may be an attempt by the organization to replace unions by influencing their functions [86]. We argue that CSR perceptions in unionized workplaces may depend on the degree of trust employees have in their organization's intentions.

The IR climate is a subset of organizational climate and describes the quality of labor-management relations in organizations [87]. It is "an umbrella-type, or molar, concept that has the capacity to convey the general psychological atmosphere of an organization, which can influence employee workplace attitudes" [88] (p. 22). Organizational IR climate may be created by organizations based on their strategy, however, as in the case of the Korean context, it is also often affected by institutional imperatives that establish the regulatory, normative, and cultural realities of business survival in different institutional environments [89,90].

IR climate can be cooperative or non-cooperative. Kaufman [91] has argued that since the 1960s employee-employer relations, especially in the US, have been seen as pluralistic, antagonistic, and conflicting. The antagonistic view of employee-management relations, though dominant in much research, is not the only view of employment relations. In recent years, there have been attempts to develop more cooperative models of industrial relations [92]. These cooperative models have examined high-commitment or high-involvement employment relations in which organizations create HPWS and promote labor-management cooperation [93]. In these systems, employees are considered the organization's most valuable resource [94]; studies written from this viewpoint emphasize workforce participation, team and group work, greater autonomy, and employee empowerment [95]. Other studies have shown that where union and management are integrated into the decision-making processes, goodwill and trust will emerge and adversarial attitudes will slowly dissipate [10].

An important question at this point is that how cooperative IR strengthens the relationship between CSR and positive employee attitudes through justice perception. We argue that cooperative IR climate emerges when management and employees realize that the gains from such relations are mutual and greater than having antagonistic employment relations [85]. This mutual desire to work together implies joint pursuance of agreed goals. These agreed goals may represent some shared and some exchange goals where some goals may benefit the management, and some may benefit the employees. Additionally, this joint activity may also signify some mechanisms and procedures of participation, discussion, and information sharing [92]. It is argued that cooperative activities that involve employees in the process of determining policies and resolving shared concerns through discussion, mutual give and take, and procedural agreements may create employee perceptions of organizational behavioral consistency and organizational integrity. In union settings, the perception of organizational integrity 
may reinforce a positive view of organizational socially responsible activities that may enhance the impact of CSR perception on employee attitudes. Additionally, reduced antagonism and improved trust may strengthen employee perceptions that they can achieve their desired goals through established procedures [10].

The preceding discussion leads to the following hypothesis:

Hypothesis 7a. The relationship between perceptions of CSR and distributive justice will be moderated by the IR climate so as to strengthen that relationship when the IR climate is cooperative rather than when it is antagonistic.

Hypothesis $7 \mathbf{b}$. The relationship between perceptions of CSR and procedural justice will be moderated by the IR climate so as to strengthen that relationship when the IR climate is cooperative rather than when it is antagonistic.

All of the presented hypotheses are reflected in our theoretical model, illustrated in Figure 1. However, research models of this configuration are recognized as moderated mediation models [72]. Therefore, we present our final hypotheses that emphasize the moderated mediation effect of IR climate:

Hypothesis 8a. IR climate moderates the mediating effect of distributive justice on the relationship between CSR and organizational affective commitment, such that the indirect effect of CSR on affective organizational commitment via distributive justice is stronger in a cooperative IR climate than in non-cooperative IR climate.

Hypothesis $\mathbf{8 b}$. IR climate moderates the mediating effect of procedural justice on the relationship between Corporate Social Responsibility (CSR) and job satisfaction, such that the indirect effect of CSR on job satisfaction via procedural justice is stronger in a cooperative IR climate than in non-cooperative IR climate.

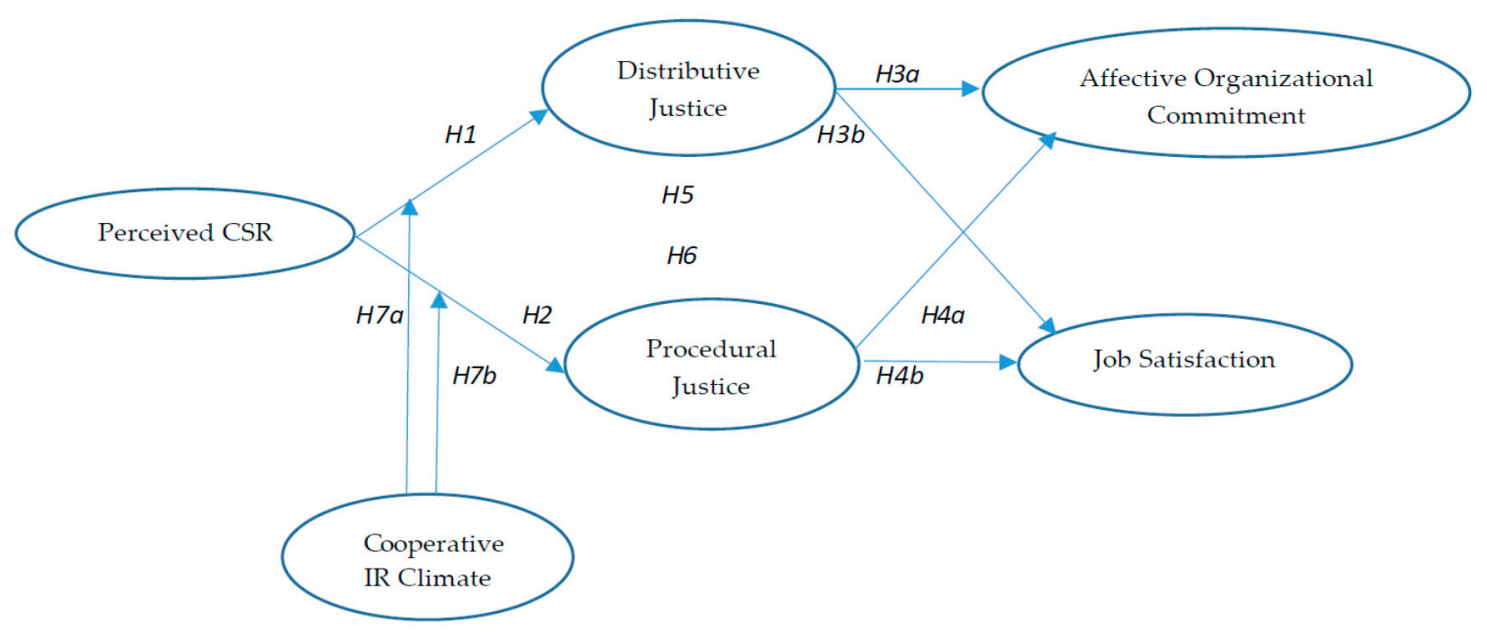

Figure 1. Theoretical Research Framework.

\section{Methodology}

\subsection{Participants}

Data for this study were collected from the unionized employees of Hyundai Motor Company (HMC) in South Korea in 2012. The sample consisted of 457 participants from four different departments, including the engine, material, and seats departments, and the assembly line. All participants were regular production workers, and $99.0 \%$ of them were male. Since most workers working on an assembly line are male in HMC, the high number of male respondents is not a sampling 
bias, as studies point out (e.g., [96]) that such a sample may provide an understanding of how workers interpret CSR through justice framework in the male-dominated workplace. The average age of these respondents was 48.71 years $(S D=4.99)$ and their average tenure was 24.73 years $(S D=4.91)$. Education varied across respondents: $84.2 \%$ had a high school diploma, and $15.8 \%$ had a bachelor's degree. Assembly department accounted for $34.8 \%$ of the sample; engine department accounted for $45.7 \%$; material department accounted for $14.4 \%$; the rest were seats department. Finally, data for this study were drawn from surveys that included the measures for perceived CSR, distributive justice, procedural justice, IR climate, organizational affective commitment, job satisfaction, union commitment, trust in management, and other demographic questions.

\subsection{Measures}

\subsubsection{Perceptions of CSR}

Since CSR is a multidimensional concept, we evaluated organizational socially responsible behaviors towards various stakeholders (i.e., employees, suppliers, and community members). We took information from the research of Hansen et al. [62] and developed four items to assess employee perceptions of organizational CSR towards the community, employees, and sub-contracted firms. We were particularly interested in work-family conflict, which research has shown to be closely related to employee concerns for CSR [97]. Work-family conflict can be seen as the cause of many organizational and social problems. Additionally, we considered organizational responsibility for supply chain companies, as they constitute one of the most important stakeholder groups [98]. We asked participants to measure CSR performance using the following items: "I think my company has a policy to reduce work-family conflict", "I think my company encourages employees to be involved in community service", "I think my company conducts charitable activities to help society", and "I think my company emphasizes partnership with sub-contracted firms." The items were scored on a five-point Likert-type rating scale with scores ranging from strongly disagree (1) to strongly agree (5). Cronbach's alpha values for all items were 0.69 for perceived CSR.

\subsubsection{Distributive and Procedural Justice}

Distributive justice measures were developed from three items utilized in Greenberg [78]. These three items accounted for employee perceptions of their input and corresponding rewards. Participants were asked to evaluate distributive justice using the following item: "I receive fair rewards in light of my (efforts, experiences, and time)". Cronbach's alpha values for all items were 0.91 . Procedural justice was measured using four items related to decision-making taken from 26 items used by Folger and Konovsky [75], who evaluate several dimensions of procedural justice (i.e., planning, resources, and observation); however, we were interested in measuring systemic and general perceptions about procedural justice. Therefore, we considered 11 of the 26 items related to feedback developed by Folger and Konovsky [75]. From these 11 items, we used four items to create a shorter version. The items with the highest factor loadings (0.67 to 0.78), as given in the study of Folger and Konovsky [75], were chosen. Although normally it is not ideal to use shortened versions, the available evidence suggests that the complete scale is highly correlated with the shortened scale. The chosen items include "I have an opportunity to express my side of the story", "I believe my company uses consistent standards in evaluating my performance", "The company is honest and fair in dealing with me", and "The company considered your views regarding your performance". A five-point Likert scale was used to measure respondent's perceptions of each item, with possible responses ranging from strongly disagree (1) to strongly agree (5). Cronbach's alpha values for all items were 0.82 .

\subsubsection{IR Climate}

Our IR climate scale consisted of four items that reflect the degree of union-management cooperation. We extracted these four items from the 23 items related to IR climate used by Angle 
and James [99]. This decision was based on considerations of space and time. Additionally, other researchers have also used shortened versions of this scale to measure IR climate [100]. The four items used reflect employee-employer cooperation, as in Hammer et al. [100], and Deery and Iverson [85]. Scores were determined on a scale ranging from strongly disagree (1) to strongly agree (5). Items include "The union and management tries to cooperate in order to reach the same goals", "The union and management share most information", "The union and management work together to try to find creative solutions to problems", and "The union and management try to understand each other". Cronbach's alpha values for all items were 0.83 for IR climate.

\subsubsection{Affective Commitment}

We assess the impact of CSR on affective commitment to client firms. Affective commitment was measured with three items taken from Mowday et al. [101] and as used by Jex and Bliese [102]. Responses were scored on five-point Likert scales ranging from 1 (strongly disagree) to 5 (strongly agree). A sample item is "I enjoy discussing my organization with people outside it" and "I really feel as if this organization's problems are my own". Affective commitment scales' coefficient alpha was 0.72 .

\subsubsection{Job Satisfaction}

Job satisfaction was measured using three items Michigan Organizational Assessment Questionnaire job satisfaction subscale. This measure was also used by Venkataramani et al. [103] representing employees' degree of satisfaction with the work itself and rewards. A sample item is "All in all, I am satisfied with my work itself". Responses were scored on five-point scales ranging from very unsatisfied (1) to very satisfied (5). Job satisfaction scales' coefficient alpha in this study was 0.75 .

\subsubsection{Control Variables}

We controlled for demographic characteristics that have been shown to influence workers' organizational commitment and job satisfaction, such as the participants' age, tenure, and education level (graduated from high school $=1$, graduated from University $=0$ ). However, we did not control for gender because $99.0 \%$ of participants were male. As the employees worked in four different buildings, we controlled for their respective departments. Additionally, we controlled for the impact of trust in management and union commitment as potential variables that might impact organizational commitment and job satisfaction. Since trust in management is based on integrity and beliefs about management, a lack of trust in management can be expected to divert an employee attitudes [104]. For this reason, trust in management may be related to organizational commitment and job satisfaction [105]. The trust-related items required responses to the following questions: "How do you trust in your (top management and plant manager)?" Participant answers were measured with five-point scale ( $1=$ strongly distrust, $5=$ strongly trust). Cronbach's alpha values for two items were 0.83 . Finally, union commitment is a subject of longstanding interest in behavioral research in unionized workplace. In the unionized organization, for instance, commitment to the union has also played an important role to shape their psychological response to their organization [106]. Prior studies have also pointed that union commitment is closely related to organizational commitment and job satisfaction $[107,108]$. Union commitment was measured with four items developed by Angle and Perry [99]. A sample item is "I am loyal to the union". Cronbach's alpha values for union commitment were 0.78 .

\section{Results}

Descriptive statistics for all variables and correlations between them are presented in Table 2. 
Table 2. Descriptive Statistics and Correlations $(N=457)$.

\begin{tabular}{lcccccccc}
\hline \multicolumn{1}{c}{ Variables } & Mean & S.E & (1) & (2) & (3) & (4) & (5) & (6) \\
\hline (1) Perception of CSR & 2.58 & 0.56 & 1 & & & & \\
(2) Procedural justice & 2.13 & 0.60 & $0.45^{* *}$ & 1 & & & & \\
(3) Distributive justice & 2.47 & 0.72 & $0.35^{* *}$ & $0.60^{* *}$ & 1 & & \\
(4) IR climate & 2.19 & 0.59 & $0.45^{* *}$ & $0.55^{* *}$ & $0.40^{* *}$ & 1 & & \\
(5) Affective commitment & 2.89 & 0.68 & $0.41^{* *}$ & $0.38^{* *}$ & $0.31^{* *}$ & $0.26^{* *}$ & 1 & \\
(6) Job satisfaction & 2.69 & 0.66 & $0.35^{* *}$ & $0.45^{* *}$ & $0.55^{* *}$ & $0.32^{* *}$ & $0.37^{* *}$ & 1 \\
(7) Union commitment & 3.53 & 0.65 & -0.04 & -0.09 & $-0.15^{* *}$ & -0.01 & 0.08 & -0.08 \\
(8) Trust in management & 2.15 & 0.74 & $0.48^{* *}$ & $0.68^{* *}$ & $0.48^{* *}$ & $0.47^{* *}$ & $0.46^{* *}$ & $0.46^{* *}-0.14^{* *}$ \\
\hline
\end{tabular}

Note: Statistically significant ${ }^{* *}$ at the 0.01 level (two-tailed tests).

\subsection{Common Method Variance}

As with all studies involving self-reported, there is the potential possibility in this study of common method variance. To remedy this problem, we conducted two tests to determine the extent of common method variance in the current analysis. First, Harman's [109] one-factor test was conducted, as suggested by Podsakoff and Organ [110]. The results identified six factors, of which the largest accounted for $12.42 \%$ of the total variance. This result suggests no serious distortion as a result of the common method effects in this study. To confirm this result, a single unmeasured latent method factor, which was used by Podsakoff et al. [111], was used in testing. The results showed that while the common method factor did improve the model fit, it accounted for only $23.74 \%$ of the total variance. This variance is far less than the $25 \%$, which has been specified in organizational psychology literature as an acceptable level of method variation [112], as also recommended by Williams et al. [113]. Siemsen et al. [114] emphasize that interaction effects cannot be artificially caused by common method variance; they argue that empirical studies should not be criticized for common method bias if the purpose of the study is to demonstrate an interaction effect. Therefore, our results suggest that common method variance is not high enough to create problems in this study.

\subsection{Confirmatory Factor Analysis}

Prior to analyzing the various regressions for testing of our hypotheses, we conducted a confirmatory factor analysis using maximum likelihood estimation to assess the discriminant validity of the substantive constructs measured in this study. We used indicators for constructs that were measured with more than two items. The results of the proposed eight-factor structure (including the following factors: perceptions of CSR, distributive justice, procedural justice, IR climate, organizational commitment, job satisfaction, union commitment, and trust in management) demonstrated a good fit with the data, as follows: We followed the suggestion of Hair et al. [115] suggestion in order to assess the model fit. The hypothesized fix-factor model fitted the data well: $\chi^{2}=780.25, p=0.00$, Tucker-Lewis Index $(\mathrm{TLI})=0.90$, comparative fit index $(\mathrm{CFI})=0.91$, root mean square error of approximation $($ RMSEA $)=0.06$. The measurement model results indicated an acceptable fit to the data; values for all indicators were statistically significant $(p<0.01)$.

We also conducted a series of confirmatory factor analyses to determine the distinctiveness of the study variables. Four other models were tested and compared against the eight-factor model. The seven-factor models respectively merged distributive justice and procedural justice (seven-factor model A) and organizational commitment and job satisfaction (seven-factor model B). We also estimated the six-factor model, which combined distributive justice and procedural justice into a single factor and organizational commitment and job satisfaction into another single factor. Finally, we estimated the five-factor model, in which perceptions of CSR were retained as a single factor, distributive justice, procedural justice, and IR climate were merged into a single factor, and organizational commitment and job satisfaction were represented as another single factor. The results indicated that the eight-factor model was a significantly better fit to the data than were the other models (Table 3). 
Table 3. Comparative Fit Indices.

\begin{tabular}{cccccccccc}
\hline & $x^{2}$ & $d f$ & CFI & TLI & RMSEA & RMSR & $\Delta x^{2}$ & $\Delta d f$ & $p$ \\
\hline Eight-factor model & 780.25 & 296 & 0.91 & 0.90 & 0.06 & 0.04 & & & $<0.01$ \\
Seven-factor model A & 1200.30 & 303 & 0.84 & 0.82 & 0.08 & 0.04 & 450.05 & 7 & $<0.01$ \\
Seven-factor model B & 1220.29 & 303 & 0.87 & 0.85 & 0.07 & 0.04 & 440.04 & 7 & $<0.01$ \\
Six-factor model & 1438.58 & 309 & 0.80 & 0.77 & 0.09 & 0.05 & 658.13 & 13 & $<0.01$ \\
Five-factor model & 1837.46 & 314 & 0.73 & 0.70 & 0.10 & 0.05 & 1057.21 & 18 & $<0.01$ \\
\hline
\end{tabular}

Note: $N=457$.

\subsection{Hypothesis Testing}

To test the proposed hypotheses, we used structural equation modeling and PROCESS. Particularly, PROCESS suggested by Hayes [116] provides indirect effects for multiple mediators and conditional indirect effects for moderated mediation models.

Using structural equation model, Figure 2 shows the mediating role of organizational justice in the relationships between CSR, organizational commitment, and job satisfaction. Hypothesis 1 states that perceived CSR is positively related to distributive justice. Our results support this view $(\beta=0.55$, $p<0.01)$. Hypothesis 2 proposes that perceived CSR is positively related to procedural justice $(\beta=0.65$, $p<0.01)$. Hypotheses $3 \mathrm{a}$ and $3 \mathrm{~b}$ suggest that distributive justice is positively related to organizational commitment $(\beta=0.21, p<0.01)$ and job satisfaction $(\beta=0.5, p<0.01)$. Finally, Hypotheses $4 \mathrm{a}$ and $4 \mathrm{~b}$ state that procedural justice is positively related to organizational commitment $(\beta=0.34, p<0.01)$ and job satisfaction as well $(\beta=0.23, p<0.01)$. Our results supported all of these hypotheses.

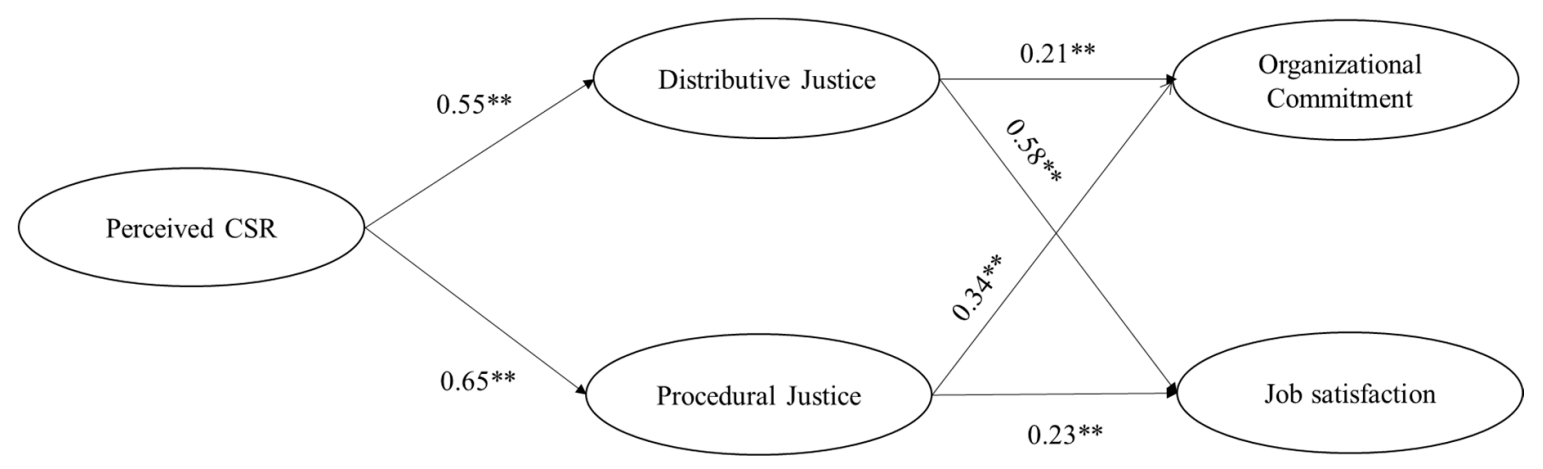

Figure 2. Structural Equation Modeling Results. ${ }^{* *} p<0.01$.

To confirm our mediator models, we tested indirect effects proposed by Preacher and Hayes [117]. With control variables, we used 10,000 bootstrap samples to construct $95 \%$ bias-corrected confidence intervals around the indirect effects. The results show significant indirect effects of CSR on organizational commitment through distributive justice (BC CI ${ }_{95 \%}=0.005$ to 0.106 ) and procedural justice ( $\mathrm{BC} \mathrm{CI}{ }_{95 \%}=$ 0.037 to 0.172$)$, because zeros were not in their respective confidence intervals. In addition, the indirect effects of CSR on job satisfaction through distributive justice (BC CI ${ }_{95}=0.110$ to 0.230 ) and procedural justice (BC CI ${ }_{95 \%}=0.023$ to 0.136 ) were significant. Thus, Hypotheses 5 and 6 were supported.

To test the moderating role of IR climate, we followed the steps recommended in Aiken and West [118], examining two suggested conditions accordingly: (1) a significant effect of the interaction between perceptions of CSR and IR climate (perceptions of CSR $\times$ IR climate) on organizational commitment and job satisfaction when IR climate is controlled; and (2) the value of R-squared after input of the moderating variable and increase of the interaction term. Prior to the analysis, we performed mean centering of the variables used in the interaction to avoid multicollinearity [118]. The results showed that while the interaction terms for the perceptions of CSR and IR climate were not significant with respect to distributive justice (second column, Table 4), they were significantly related to procedural justice $\left(\beta=0.07, p<0.05, \Delta \mathrm{R}^{2}=0.01, p<0.05\right.$; fourth column, Table 4 ). Figure 3 displays 
the nature of the interaction. Values representing \pm 1 standard deviation from the mean are used to reflect higher and lower levels of influence of IR climate. The graph for the CSR-procedural justice relationship with perceptions of high IR climate is steeper than that for employees with perceptions of low IR climate, which indicates that IR climate strengthens the positive impact of perceptions of CSR on procedural justice. Therefore, Hypothesis $7 \mathrm{a}$ was not supported, but Hypothesis $7 \mathrm{~b}$ was supported.

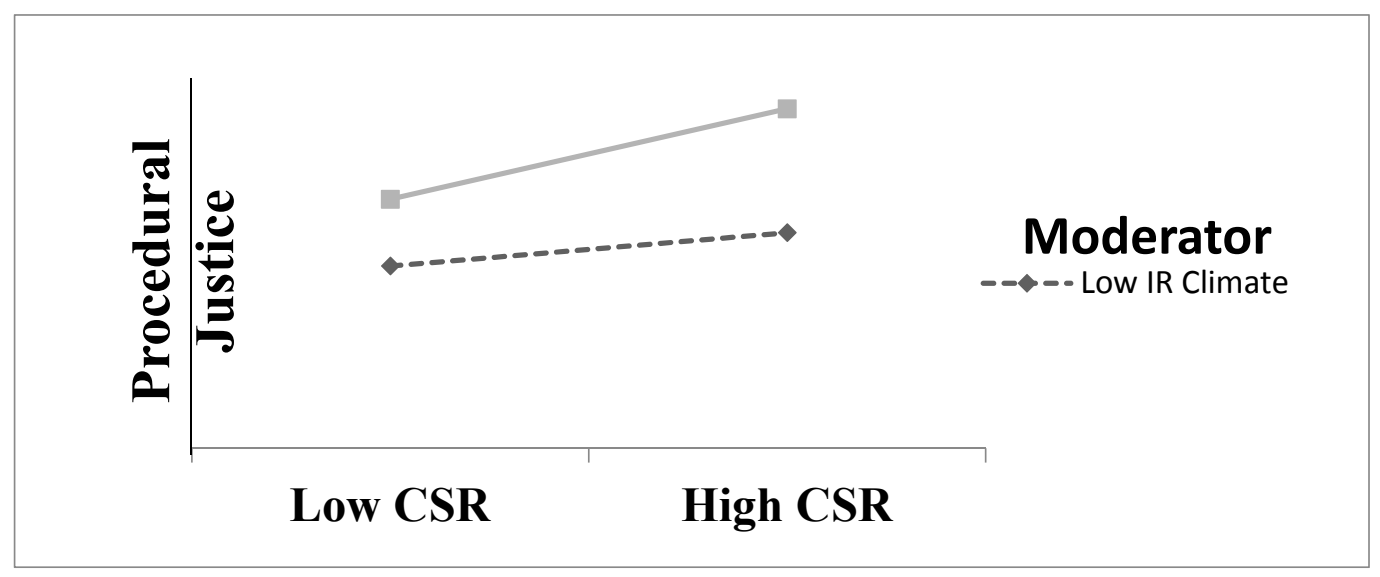

Figure 3. Interaction Effect between CSR Perceptions and IR Climate on Procedural Justice.

Table 4. Results of Regression Analysis $(N=457)$.

\begin{tabular}{ccccc}
\hline & $\mathbf{1}$ & $\mathbf{2}$ & $\mathbf{3}$ & $\mathbf{4}$ \\
\cline { 2 - 5 } & \multicolumn{2}{c}{ Distributive Justice } & \multicolumn{2}{c}{ Procedural Justice } \\
\hline Age & -0.10 & -0.11 & $0.12^{*}$ & 0.11 \\
Tenure & -0.06 & -0.05 & $-0.21^{* * *}$ & $-0.21^{* * *}$ \\
Education & 0.04 & 0.04 & 0.02 & 0.03 \\
Department (Assembly) & -0.06 & -0.06 & -0.00 & 0.01 \\
Department (Engine) & $0.07^{*}$ & $0.07^{*}$ & 0.05 & 0.05 \\
Department (Material) & 0.01 & 0.01 & -0.00 & -0.01 \\
Union commitment & $-0.13^{* * *}$ & $-0.13^{* * *}$ & -0.02 & -0.03 \\
Trust in management & $0.35^{* * *}$ & $0.35^{* * *}$ & $0.52^{* * *}$ & $0.52^{* * *}$ \\
Perception of CSR & $0.11^{* *}$ & $0.11^{* *}$ & $0.08^{* *}$ & $0.10^{* *}$ \\
IR climate & $0.19^{* * *}$ & $0.18^{* * *}$ & $0.27^{* * *}$ & $0.26^{* * *}$ \\
IR climate* CSR perception & & 0.04 & & $0.07^{* *}$ \\
Adjust $\mathrm{R}^{2}$ & 0.32 & 0.32 & 0.55 & 0.56 \\
$\mathrm{R}^{2}$ Change & & 0.00 & & $0.01^{* *}$ \\
\hline
\end{tabular}

Statistically significant ${ }^{*}$ at the 0.10 level, ${ }^{* *}$ at the 0.05 level, ${ }^{* * *}$ at the 0.01 level (two-tailed tests). The seats department is reference variable, Education ( 1 = graduate University, $0=$ graduate High School).

To test the proposed moderated mediation effects, we examined the conditional indirect effect of CSR on affective commitment through IR climate at three values of moderator: the mean, one standard deviation above the mean, and one standard deviation below the mean. Table 4 presents the estimates, standard errors, and $95 \%$ confidence intervals of the conditional indirect effects across three levels of IR climate. As shown in Table 4, 95\% confidence interval values of the indirect effects at the one standard deviation below the mean of IR climate do include zero $(-0.006,0.026)$, whereas the mean $(0.001,0.041)$ and one standard deviation above the mean of IR climate do not include zero $(0.001,0.064)$. That is, there is no evidence of these indirect effects among those low levels of IR climate. The results show that the conditional indirect effects were strong and significant at high levels of IR climate but were not significant at the low levels of IR climate. Therefore, the indirect effect of CSR on affective commitment through procedural justice is contingent on IR climate was supported. Similarly, we tested the effect of CSR on job satisfaction via procedural justice. The result supported the effect of CSR on job satisfaction 
through procedural justice depends on IR climate (Hypothesis $8 b$ ), because $95 \%$ confidence interval values of the indirect effects at the one standard deviation below the mean of IR climate do include zero $(-0.014,0.035)$ whereas the mean $(0.003,0.057)$ and one standard deviation above the mean of IR climate do not include zero $(0.007,0.094)$ in Table 5.

Table 5. Bootstrapping Results for Conditional Indirect Effects of CSR on Affective Commitment and Job Satisfaction at Value of the Moderator.

\begin{tabular}{cccccc}
\hline & & Conditional & Boot & \multicolumn{2}{c}{ 95\% CI } \\
\hline Dependent Variable & Moderator Level & Indirect Effect & SE & Boot LLCI & Boot ULCI \\
\hline Affective commitment & Low $(-0.593)$ & 0.005 & 0.007 & -0.004 & 0.027 \\
Affective commitment & 0.000 & 0.013 & 0.009 & 0.001 & 0.041 \\
Affective commitment & High $(0.593)$ & 0.022 & 0.015 & 0.001 & 0.063 \\
Job satisfaction & Low $(-0.593)$ & 0.010 & 0.013 & -0.012 & 0.039 \\
Job satisfaction & 0.000 & 0.028 & 0.014 & 0.005 & 0.063 \\
Job satisfaction & High $(0.593)$ & 0.045 & 0.023 & 0.010 & 0.100 \\
\hline
\end{tabular}

Results are based on 10,000 bootstrap samples, mean centering was conducted.

\section{Discussion}

\subsection{Results and Their Explanation}

We have determined that perceived CSR is a strong predictor of affective organizational commitment and job satisfaction, and the impact of CSR on affective organizational commitment and job satisfaction is fully mediated by both procedural and distributive justice. We have also found the unique moderated-mediating impact of a collaborative IR climate on the relationship between CSR perceptions and procedural justice, and affective organizational commitment and job satisfaction. However, no significant moderated-mediating effect of IR climate was identified in the relationship between perceived CSR, distributive justice, and our dependent variables.

Scholars have argued that CSR behavior of business organizations varies across countries and, therefore, there is a need to pay more attention to national institutional contexts [33,119]. Our findings regarding the role of IR climate can be explained through the Korean institutional setup. The Korean state has created institutional imperatives for Korean businesses to improve their CSR profile [20] and install cooperative employment relations [12]. On the other hand, Korea has gone through the process of democratization and union militancy, which suggests that the Korean workers are actively protecting their rights and are interested in organizational justice [11,14]. Heightened industrial cooperation in the Korean employment relations, suggests that unions have moved from antagonistic to cooperative relations with their employees [16]. In other words, unions have somewhat adapted to the collaborative and socially responsible institutional milieu created by the state. Therefore, in the Korean union setting, employees may consider organizational justice necessary and may perceive improved CSR profiles, which represents organizational norms of fair treatment of all stakeholders, of their organizations as an essential ingredient of organizational justice.

Similarly, heightened industrial cooperation and greater emphasis on HPWS could improve the employee perception of their standing in the organization [11,13]. Hence, further strengthening the relationship between CSR and justice perception, where organizational CSR stresses on treating employees as important internal stakeholders. Finally, we have not found that IR climate has a significant moderated-mediating effect on the relationship between CSR perceptions, distributive justice, and the dependent variables. First explanation for these findings may be that HMC as a firm (and Korean employment relations in general) is moving towards more cooperative and collaborative employee-management relations $[21,26]$. With the greater involvement of employee representatives in the IR process, employee's understanding and view of organizational institutions and procedures have undoubtedly improved (procedural justice). However, a better comprehension of the IR system does not necessarily mean that employees are satisfied with their personal rewards and outcomes. 
Additionally, the employees are interacting with HMC through their unions, hence, whatever they are receiving in terms of personal rewards and outcomes may have been perceived as more of a union benefit than organizational distributive justice.

\subsection{Theoretical Implications}

Our results confirm the findings of existing empirical studies that employees' CSR perceptions have a significant impact on their organizational affective commitment and job satisfaction $[2,3,53,54,57]$. However, our study has made some significant theoretical contributions to the extant literature on CSR and its impact on employee attitudes.

First, our study introduces two new theories, i.e., heuristic and deontic fairness, to explain the cognitive process underpinning the relationship between CSR and justice, and CSR and employee attitudes. This addition makes a significant theoretical contribution to the existing psychological foundations, i.e., SIT and SET, applied in the extant literature to explain the studied relationships. This contribution is significant as it highlights the ethics-based core of both CSR and justice and explain the studied impact not based on instrumental or relational human needs but on an evolved non-egocentric need of justice predicated on the universal principles of human dignity and fair treatment.

Second, our study underscores the pivotal importance of the concept of justice in the relationship between CSR and employee attitudes. We do so by introducing new psychological mechanisms, i.e., heuristic and deontic fairness theories, and two main types of justice as mediators, i.e., distributive and procedural justice. Our findings give empirical support to the role of organizational justice in the CSR context as suggested by Rupp et al. [39]. Furthermore, our findings extend De Roeck and colleagues' [54] empirical contribution that suggests the mediating role of overall justice to explain the relationship between CSR perception and employee attitudes.

Third, a singular contribution of our study is that we have tested the moderated-mediating effect of IR climate in the context of CSR. By including this variable, we have tried to address the need to consider the relationship between institutional and organizational setups and organizational policy. This empirical study, in essence, improves upon the existing CSR literature, where discussion of the role of unions and employee-management relations in the context of organizational social responsibility is almost absent.

\subsection{Practical Implications, Limitations, and Future Directions}

The study has two important practical implications. First, justice is an important ingredient in the employment relations. Organizational policies related to both CSR and employee-employer cooperation in union settings must acknowledge its importance. Hence, management should conduct its affairs with all its stakeholders in a fair, transparent manner with the intent to develop long-term relations. Second, in union settings, management may foster union-management cooperation to strengthen the relationship between CSR and perceptions of justice among employees and employee positive attitudes. In other words, the two separate policies of organizational CSR and cooperative employee relations may have a synergetic effect on employee attitudes.

Despite its several theoretical and practical contributions, this work is not without its limitations. First, the analyses for this study were performed on a relatively large sample. However, the generalizability of results may be limited because the data is drawn from a single organization in one country. Therefore, we cannot explicitly exclude possible effects of HMC's unique organizational context and the Korean culture. To improve generalizability, we suggest that future researchers collect data from diverse organizations across different nations.

Second, all variables measured in this study were drawn from survey data. Consequently, this method may have the potential problem of common method bias. Although we conducted tests to rule out common method bias and to confirm no serious distortion of the results has occurred, the problem of common method bias may persist to some extent in any study with data from a single source [111]. We, therefore, suggest that future researchers should include multiple sources in testing 
CSR and its effects on employee outcomes and attitudes. Finally, our results show positive effects of CSR initiatives on employee attitudes. However, the link between these positive attitudes and organizational performance was not examined in this study. Therefore, we suggest that future scholars should include various performance indicators that are predictable in the relationships between CSR and firm performance, improved employee attitudes, and behavior at the individual level. We also suggest a multilevel analysis as a useful avenue for future research.

\section{Conclusions}

In essence, we have attempted to improve our understanding of the relationship between CSR and positive employee attitudes by making two contributions. First, we have given the rightful place to the concept of justice in the relationship between CSR and positive employee attitudes by explicating this relationship through two main types of justices, i.e., distributive and procedural. Additionally, we propose ethics-based cognitive processes, i.e., heuristic and deontic fairness, to explain the studied relationships in our model. By doing so, we underscore the view that the impact of CSR and justice on employee attitudes cannot be fully understood without discussing their ethical or moral implications. Second, we test our model in a specific IR climate, i.e., cooperative IR, with the argument that a cooperative employee-employer relationship in a union setting will enhance the impact of CSR perception on employee attitudes. The most important implication of our findings is that sustainable management practices that focus on internal social responsibility may have a greater positive impact on employee attitudes if supportive practices based on justice and cooperation are also practiced in unison.

Acknowledgments: No funding sources were used for this study. We have received funds for open access.

Author Contributions: Heung-Jun Jung and Ali conceived the model by reading and discussing the existing literature. Heung-Jun Jung collected and analyzed the data. Ali and Heung-Jun Jong discussed the analysis strategy and methodology. Ali wrote the paper with inputs from Heung-Jun Jung.

Conflicts of Interest: The authors declare no conflict of interest.

\section{References}

1. Peterson, D. The relationship between perceptions of corporate citizenship and organizational commitment. Bus. Soc. 2004, 43, 296-319. [CrossRef]

2. Brammer, S.; Millington, A.; Rayton, B. The contribution of corporate social responsibility to organizational commitment. Int. J. Hum. Resour. Manag. 2007, 18, 1701-1719. [CrossRef]

3. Valentine, S.; Fleischman, G. Ethics programs, perceived corporate social responsibility and job satisfaction. J. Bus. Ethics. 2008, 77, 159-172. [CrossRef]

4. Vlachos, P.A.; Theotokis, A.; Panagopoulos, N.G. Sales force reactions to corporate social responsibility: Attributions, outcomes, and the mediating role of organizational trust. Ind. Market. Manag. 2010, 39, 1207-1218. [CrossRef]

5. Kim, W.; Park, J. Examining structural relationships between work engagement, organizational procedural justice, knowledge sharing, and innovative work behavior for sustainable organizations. Sustainability 2017, 9, 205. [CrossRef]

6. Hofman, P.; Newman, A. The impact of perceived corporate social responsibility on organizational commitment and the moderating role of collectivism and masculinity: Evidence from China. Int. J. Hum. Resour. Manag. 2014, 25, 631-652. [CrossRef]

7. Rupp, D.; Wright, P.; Aryee, S.; Luo, Y. Organizational justice, behavioral ethics, and corporate social responsibility: Finally the three shall merge. Manag. Organ. Rev. 2015, 11, 15-24. [CrossRef]

8. Cropanzano, R.; Goldman, B.; Folger, R. Deontic justice: The role of moral principles in workplace fairness. J. Organ. Behav. 2003, 24, 1019-1024. [CrossRef]

9. Bhattacharya, C.B.; Kors, D.; Sen, S. Strengthening stakeholder-company relationships through mutually beneficial corporate social responsibility initiatives. J. Bus. Ethics 2009, 85, 257-272. [CrossRef]

10. Deery, S.; Iverson, R.; Erwin, P. Industrial relations climate, attendance behaviour and the role of trade unions. Br. J. Ind. Relat. 1999, 37, 533-558. [CrossRef] 
11. Kong, T.Y. Cooperation in unlikely settings: The rise of cooperative labor relations among leading South Korean firms. Politics Soc. 2012, 40, 425-452. [CrossRef]

12. Kim, D.; Ahn, J. Industrial relations in Korea: Focusing on developments since the 1997-1998 financial crisis. Korean Acad. Manag. Int. Symp. 2011, 19, 109-133.

13. Kim, H.; Park, J. Rebuilding the employee representation system: Necessity and basic direction. E-Labor News 2012, 123, 1-21.

14. Frenkel, S.; Lee, B.-H. Do high performance work practices work in South Korea? Ind. Relat. J. 2010, 41, 479-504. [CrossRef]

15. Kim, D.-O.; Kim, H. A comparison of the effectiveness of unions and non-union works councils in Korea: Can non-union employee representation substitute for trade unionism? Int. J. Hum. Resour. Manag. 2004, 15, 1069-1094. [CrossRef]

16. Dong-Heon, K.; Feuille, P. Works councils in Korea: Implications for employee representation in the United States. In Proceedings of the Fiftieth Annual Meeting of the Industrial Relations Research Association (IRRA), Madison, WI, USA; 1998; pp. 146-154.

17. Lee, J.; Kim, D. The effects and determinants of the high performance organizational systems in Korea. Korean J. Ind. Relat. 2007, 17, 1-38. (In Korean)

18. Federation of Korean Industries. The Ethical Business Reports on Results of CSR; Federation of Korean Industries: Seoul, Korean, 2011.

19. Kim, D.; Choi, M. A comparison of young publics' evaluation of corporate responsibility practices of multinational corporations in the United States and South Korea. J. Bus. Ethics 2012, 113, 105-118. [CrossRef]

20. Kim, C.H.; Amaeshi, K.; Harris, S.; Suh, C. CSR and the national institutional context: The case of South Korea. J. Bus. Res. 2013, 66, 2581-2591. [CrossRef]

21. Lansbury, R.; Kwon, S.; Suh, C. Globalization and employment relations in the Korean auto industry: The case of the Hyundai Motor Company in Korea, Canada and India. Asia Pac. Bus. Rev. 2006, 12, 131-147. [CrossRef]

22. Steers, R.M.; Shin, Y.; Ungson, G. The Chaebol: Korea's New Industrial Relations Might; Harper and Row: New York, NY, USA, 1989.

23. Sustainability Report. 2014. Available online: https:// csr.hyundai.com (accessed on 2 August 2017).

24. Cho, H.J. The employment adjustment of Hyundai Motor Company: A research focus on corporate-level labour relations. Korean J. Lab. Stud. 1999, 5, 63-96. (In Korean)

25. Lee, J. Company and union commitment: Evidence from an adversarial industrial relations climate at a Korean auto plant. Int. J. Hum. Resour. Manag. 2004, 15, 1463-1480. [CrossRef]

26. Song, J. Economic distress, labor market reforms, and dualism in Japan and Korea. Int. J. Policy Adm. Inst. 2012, 25, 415-438. [CrossRef]

27. Carroll, A.B. A three-dimensional conceptual model of corporate performance. Acad. Manag. Rev. 1979, 4, 497-505.

28. Carroll, A.B. The pyramid of corporate social responsibility: Toward the moral management of organizational stakeholders. Bus. Horiz. 1991, 34, 39-48. [CrossRef]

29. Carroll, A.B. Corporate social responsibility: Evolution of a definitional construct. Bus. Soc. 1999, 38, $268-295$. [CrossRef]

30. Wood, D.J. Corporate social performance revisited. Acad. Manag. Rev. 1991, 16, 691-718.

31. Jamali, D.; Neville, B. Convergence versus divergence of CSR in developing countries: An embedded multi-layered institutional lens. J. Bus. Ethics 2011, 102, 599-621. [CrossRef]

32. Margolis, J.; Walsh, J. People and Profits? The Search for a Link between a Company's Social and Financial Performance; Lawrence Erlbaum Associates: Mahwah, NJ, USA, 2001.

33. Orlitzky, M.; Schmidt, F.; Rynes, S. Corporate social and financial performance: A meta-analysis. Organ. Stud. 2003, 24, 403-441. [CrossRef]

34. Endrikat, J.; Guenther, E.; Hoppe, H. Making sense of conflicting empirical findings: A meta-analytic review of the relationship between corporate environmental and financial performance. Eur. Manag. J. 2014, 32, 735-751. [CrossRef]

35. Martínez-Ferrero, J.; Frías-Aceituno, J.V. Relationship between sustainable development and financial performance: International empirical research. Bus. Strategy Environ. 2013, 24, 20-39. [CrossRef] 
36. Shin, I.; Hur, W.M.; Kang, S. Employees' perceptions of corporate social responsibility and job performance: A sequential mediation model. Sustainability 2016, 8, 493. [CrossRef]

37. Greening, D.; Turban, D. Corporate social performance as a competitive advantage in attracting a quality workforce. Bus. Soc. 2000, 39, 254-280. [CrossRef]

38. Turban, D.; Greening, D. Corporate social performance and organizational attractiveness to prospective employees. Acad. Manag. J. 1997, 40, 658-672. [CrossRef]

39. Rupp, D.; Ganapathi, J.; Aguilera, R.; Williams, C. Employee reactions to corporate social responsibility: An organizational justice framework. J. Organ. Behav. 2006, 27, 537-543. [CrossRef]

40. Rodrigo, P.; Arenas, D. Do Employees care about CSR programs? A typology of employees according to their attitudes. J. Bus. Ethics 2008, 83, 265-283. [CrossRef]

41. Turker, D. How corporate social responsibility influences organizational commitment. J. Bus. Ethics 2009, 89, 189-204. [CrossRef]

42. Kim, H.R.; Lee, M.; Lee, H.; Kim, N. Corporate social responsibility and employee-company identification. J. Bus. Ethics 2010, 95, 557-569. [CrossRef]

43. Haski-Leventhal, D.; Roza, L.; Meijs, L.C.P.M. Congruence in corporate responsibility: Connecting the identity and behavior of employers and employees. J. Bus. Ethics 2017, 143, 35-51. [CrossRef]

44. Hameed, I.; Riaz, Z.; Arain, G.A.; Farooq, O. How do internal and external CSR affect employees' organizational identification? A perspective from the group engagement model. Front. Psychol. 2016, 7, 1-13. [CrossRef] [PubMed]

45. Fryzel, B.; Seppala, N. The effect of CSR evaluations on affective attachment to CSR in different identity orientation firms. Bus. Ethics Eur. Rev. 2016, 25, 310-326. [CrossRef]

46. De Roeck, K.; Maon, F. Building the theoretical puzzle of employees' reactions to corporate social responsibility: An integrative conceptual framework and research agenda. J. Bus. Ethics 2016. [CrossRef]

47. De Roeck, K.; El Akremi, A.; Swaen, V. Consistency matters! How and when does corporate social responsibility affect employees' organizational identification? J. Manag. Stud. 2016, 53, 1141-1168. [CrossRef]

48. De Jong, M.D.T.; van der Meer, M. How does it fit? Exploring the congruence between organizations and their corporate social responsibility (CSR) activities. J. Bus. Ethics 2017, 143, 71-83. [CrossRef]

49. Du, S.; Bhattacharya, C.B.; Sen, S. Corporate social responsibility, multi-faceted job-products, and employee outcomes. J. Bus. Ethics 2015, 131, 319-335. [CrossRef]

50. Slack, R.E.; Corlett, S.; Morris, R. Exploring employee engagement with (corporate) social responsibility: A social exchange perspective on organizational participation. J. Bus. Ethics 2015, 127, 537-548. [CrossRef]

51. Glavas, A.; Kelley, K. The effects of perceived corporate social responsibility on employee attitudes. Bus. Ethics Q. 2014, 24, 165-202. [CrossRef]

52. Tsai, Y.H.; Joe, S.W.; Lin, C.P.; Wang, R.T. Modeling job pursuit intention: Moderating mechanisms of socio-environmental consciousness. J. Bus. Ethics 2014, 125, 287-298. [CrossRef]

53. Farooq, O.; Payaud, M.; Merunka, D.; Valette-Florence, P. The impact of corporate social responsibility on organizational commitment: Exploring multiple mediation mechanisms. J. Bus. Ethics 2014, 125, 563-580. [CrossRef]

54. De Roeck, K.; Marique, G.; Stinglhamber, F.; Swaen, V. Understanding employees' responses to corporate social responsibility: Mediating roles of overall justice and organizational identification. Int. J. Hum. Resour. Manag. 2014, 25, 91-112. [CrossRef]

55. Lee, E.M.; Park, S.Y.; Lee, H.J. Employee perception of CSR activities: Its antecedents and consequences. J. Bus. Res. 2013, 66, 1716-1724. [CrossRef]

56. Glavas, A.; Godwin, L.N. Is the perception of 'goodness' good enough? Exploring the relationship between perceived corporate social responsibility and employee organizational identification. J. Bus. Ethics 2013, 114, 15-27. [CrossRef]

57. You, C.S.; Huang, C.; Wang, H.; Liu, K.; Un, C.; Tseng, J. The relationship between corporate social responsibility, job satisfaction and organizational commitment. Int. J. Organ. Innov. 2013, 5, 65.

58. McShane, L.; Cunningham, P. To thine own self be true? Employees' judgments of the authenticity of their organization's corporate social responsibility program. J. Bus. Ethics 2012, 108, 81-100. [CrossRef]

59. Mueller, K.; Hattrup, K.; Spiess, S.O.; Lin-Hi, N. The effects of corporate social responsibility on employees' affective commitment: A cross-cultural investigation. J. Appl. Psychol. 2012, 97, 1186-1200. [CrossRef] [PubMed] 
60. Bauman, C.W.; Skitka, L.J. Corporate social responsibility as a source of employee satisfaction. Res. Organ. Behav. 2012, 32, 63-86. [CrossRef]

61. De Roeck, K.; Delobbe, N. Do environmental CSR initiatives serve organizations' legitimacy in the oil industry? Exploring employees' reactions through organizational identification theory. J. Bus. Ethics 2012, 110, 397-412. [CrossRef]

62. Hansen, D.; Dunford, B.; Boss, A.; Boss, W.; Angermeier, I. Corporate social responsibility and the benefits of employee trust: A cross-disciplinary perspective. J. Bus. Ethics 2011, 102, 29-45. [CrossRef]

63. Herrbach, O.; Mignonac, K. How organizational image affects employee attitudes. Hum. Resour. Manag. J. 2004, 14, 76-88. [CrossRef]

64. Gillespie, J.Z.; Greenberg, J. Are the goals of organizational justice self-interested? In Handbook of Organizational Justice; Greenberg, J., Colquitt, J.A., Eds.; Psychology Press: London, UK, 2005.

65. Tyler, T.R.; Lind, E.A. A relational model of authority in groups. In Advances in Experimental Social Psychology; Zanna, M.P., Ed.; Academic Press: San Diego, CA, USA, 1992; Volume 99, pp. 115-191.

66. Folger, R.; Cropanzano, R.; Goldman, B. What is the relationship between justice and morality? In Handbook of Organizational Justice; Colquitt, J.A., Ed.; Greenberg: Washington, DC, USA, 2005; pp. 215-245.

67. Cropanzano, R.; Byrne, Z.; Bobocel, R.; Rupp, D. Moral virtues, fairness heuristics, social entities, and other denizens or organizational justice. J. Vocat. Behav. 2001, 58, 164-209. [CrossRef]

68. Gaus, G.F. Social Philosophy; M. E. Sharpe: Armonk, NY, USA, 1999.

69. Kahneman, D.; Knetsch, J.L.; Thaler, R.H. Fairness and the assumptions of economics. J. Bus. 1986, 59, 285-300. [CrossRef]

70. Turillo, C.J.; Folger, R.; Lavelle, J.J.; Umphress, E.; Gee, J. Is virtue its own reward? Self-sacrificial decisions for the sake of fairness. Organ. Behav. Hum. Decis. Process. 2002, 89, 839-865. [CrossRef]

71. Goffman, E. Self-presentation. In The Goffman Reader; Lemert, C., Branaman, A., Eds.; Blackwell: Oxford, UK, 1997; Chapter 2; pp. 21-26.

72. Cropanzano, R.; Mitchell, M.S. Social exchange theory: An interdisciplinary review. J. Manag. 2005, 31, 874-900. [CrossRef]

73. Rupp, D.; Williams, C.; Aguilera, R. Increasing corporate social responsibility through stakeholder value internalization (and the catalyzing effect of new governance): An application of organizational justice, self-determination, and social influence theories. Manag. Ethics Manag. Psychol. Moral. 2011, 69-88. Available online: https: / web.northeastern.edu/ruthaguilera/wp-content/uploads/2017/02/12.-Rupp-WilliamsAguilera-2011-RPP.pdf (accessed on 2 August 2017).

74. Frenkel, S.; Restubog, S.; Bednall, T. How employee perceptions of HR policy and practice influence discretionary work effort and co-worker assistance: Evidence from two organizations. Int. J. Hum. Resour. Manag. 2012, 23, 4193-4210. [CrossRef]

75. Folger, R.; Konovsky, M. Effects of procedural and distributive justice on reactions to pay raise decisions. Acad. Manag. J. 1989, 32, 115-130. [CrossRef]

76. Colquitt, J.; Conlon, D.; Wesson, M.J.; Porter, C.; Ng, K.Y. Justice at the millennium: A meta-analytic review of 25 years of organizational justice research. J. Appl. Psychol. 2001, 86, 425-445. [CrossRef] [PubMed]

77. McFarlin, D.; Sweeney, P. Research notes. Distributive and procedural justice as predictors of satisfaction with personal and organizational outcomes. Acad. Manag. J. 1992, 35, 626-637. [CrossRef]

78. Greenberg, J. Using socially fair treatment to promote acceptance of a work site smoking ban. J. Appl. Psychol. 1994, 79, 288-297. [CrossRef] [PubMed]

79. Clay-Warner, J.; Reynolds, J.; Roma, P. Organizational justice and job satisfaction: A test of three competing models. Soc. Justice Res. 2005, 18, 391-409. [CrossRef]

80. Lind, A.; Tyler, T. A relational model of authority in groups. Adv. Exp. Soc. Psychol. 1992, 25, 115-192.

81. Jaworski, B.; Kohli, A. Market orientation: Antecedents and consequences. J. Manag. 1993, 57, 53-70. [CrossRef]

82. Gouldner, A.W. The norm of reciprocity: A preliminary statement. Am. Soc. Rev. 1960, 34, 161-178. [CrossRef]

83. Janssen, O. Fair perception as a moderator in the curvilinear relationships between job demands, and job performance and job satisfaction. Acad. Manag. J. 2001, 44, 1039-1050. [CrossRef]

84. Guest, D.; Peccei, R. Partnership at work: Mutuality and the balance of advantage. Br. J. Ind. Relat. 2001, 39, 207-236. [CrossRef] 
85. Deery, S.J.; Iverson, R.D. Labor-management cooperation: Antecedents and impact on organizational performance. ILR Rev. 2005, 58, 588-609. [CrossRef]

86. Justice, D.W. Corporate Social Responsibility: Challenges and Opportunities for Trade Unionists. 2002. Available online: http:/ / digitalcommons.ilr.cornell.edu / cgi/viewcontent.cgi?article=1009\&context=codes (accessed on 2 August 2017).

87. Katz, H.; Kochan, T.; Gobeille, K. Industrial relations performance, economic performance, and QWL programs: An interplant analysis. Ind. Labor Relat. Rev. 1983, 37, 3-17. [CrossRef]

88. Dastmalchian, A.; Blyton, P.; Adamson, R. Industrial relations climate: Testing a construct. J. Occup. Organ. Psychol. 1989, 62, 21-32.

89. DiMaggio, P.J. State expansion and organization fields. In Organization Theory and Public Policy; Hall, R.H., Quinn, R.E., Eds.; Sage Publications: Beverly Hills, CA, USA, 1983; pp. 147-161.

90. Scott, W.R. Approaching adulthood: The maturing of institutional theory. Theory Soc. 2008, 37, 427-442. [CrossRef]

91. Kaufman, B.E. Paradigms in industrial relations: Original, modern and version in-between. Br. J. Ind. Relat. 2008, 46, 314-339. [CrossRef]

92. Guest, D.; Brown, W.; Peccei, R.; Huxley, K. Does partnership at work increase trust? An analysis based on the 2004 workplace employment relations survey. Ind. Relat. J. 2008, 39, 124-152. [CrossRef]

93. Tomer, J. Understanding high performance work systems: The joint contribution of economics and human resource management. J. Soc.-Econ. 2001, 30, 63-73. [CrossRef]

94. Straw, R.; Heckscher, C. QWL: New working relationships in the communication industry. Labor Stud. J. 1984, 9, 261-274.

95. Paul, R.; Niehoff, B.; Turnley, W. Empowerment, expectations, and the psychological contract-managing the dilemmas and gaining the advantages. J. Soc.-Econ. 2000, 29, 471-485. [CrossRef]

96. Ramamoorthy, N.; Flood, P.C. Gender and employee attitudes: The role of organizational justice perceptions. Br. J. Manag. 2004, 15, 247-258. [CrossRef]

97. Guitián, G. Conciliating work and family: A Catholic social teaching perspective. J. Bus. Ethics 2009, 88, 513-524. [CrossRef]

98. Maloni, M.J.; Brown, M. Corporate social responsibility in the supply chain: An application in the food industry. J. Bus. Ethics 2006, 68, 35-52. [CrossRef]

99. Angle, H.L.; James, L.P. Dual commitment and labor-management relationship climates. Acad. Manag. J. 1986, 29, 31-50. [CrossRef]

100. Hammer, T.; Currall, S.; Stern, R. Worker representation on boards of directors: A study of competing roles. Ind. Labor Relat. Rev. 1991, 44, 661-680. [CrossRef]

101. Mowday, R.T.; Porter, L.; Steers, R. Organizational Linkages: The Psychology of Commitment, Absenteeism, and Turnover; Academic Press: New York, NY, USA, 1982.

102. Jex, S.M.; Bliese, P. Efficacy beliefs as a moderator of the impact of work-related stressors: A multilevel study. J. Appl. Psychol. 1999, 84, 349-361. [CrossRef] [PubMed]

103. Venkataramani, V.; Labianca, G.; Grosser, T. Positive and negative workplace relationships, social satisfaction, and organizational attachment. J. Appl. Psychol. 2013, 98, 1028-1039. [CrossRef] [PubMed]

104. Mayer, R.; Gavin, M. Trust in management and performance: Who minds the shop while the employees watch the boss? Acad. Manag. J. 2005, 48, 874-888. [CrossRef]

105. Laschinger, H.; Finegan, J.; Shamian, J.; Wilk, P. Impact of structural and psychological empowerment on job strain in nursing work settings: Expanding Kanter's model. J. Nurs. Admin. 2001, 31, 260-272. [CrossRef]

106. Gordon, M.; Beauvais, L.; Ladd, R. The job satisfaction and union commitment of unionized engineers. Ind. Labor Relat. Rev. 1984, 37, 359-370. [CrossRef]

107. Fullagar, C.; Barling, J. A Longitudinal test of a model of the antecedents and consequences of union loyalty. J. Appl. Psychol. 1989, 74, 213-227. [CrossRef]

108. Iverson, R.; Kuruvilla, S. Antecedents of union loyalty: The influence of individual dispositions and organizational context. J. Organ. Behav. 1995, 16, 557-582. [CrossRef]

109. Harman, H. Modern Factor Analysis; University of Chicago Press: Chicago, IL, USA, 1976.

110. Podsakoff, P.M.; Organ, D. Self-reports in organizational research: Problems and prospects. J. Manag. 1986, 12, 531-544. [CrossRef] 
111. Podsakoff, P.M.; MacKenzie, S.; Lee, J.; Podsakoff, N. Common method biases in behavioral research: A critical review of the literature and recommended remedies. J. Appl. Psychol. 2003, 88, 879-903. [CrossRef] [PubMed]

112. Bagozzi, R.P.; Youjae, Y.; Lynn, P. Assessing construct validity in organizational research. Admin. Sci. Q. 1991, 36, 421-458. [CrossRef]

113. Williams, L.J.; Cote, J.; Buckley, R. Lack of method variance in self-reported affect and perceptions at work: Reality or artifact? J. Appl. Psychol. 1989, 74, 462.

114. Siemsen, E.; Roth, A.; Oliveira, P. Common method bias in regression models with linear, quadratic, and interaction effects. Organ. Res. Methods 2010, 13, 456-476. [CrossRef]

115. Hair, J.; Anderson, R.; Tatham, R.; Black, W. Multivariate Data Analysis, 5th ed.; Prentice Hall: Upper Saddle River, NJ, USA, 1998.

116. Hayes, A.F. Introduction to Mediation, Moderation, and Conditional Process Analysis: A Regression-Based Approach; Guilford Press: New York, NY, USA, 2013.

117. Preacher, K.; Hayes, A. Asymptotic and resampling strategies for assessing and comparing indirect effects in multiple mediator models. Behav. Res. Methods 2008, 40, 879-891. [CrossRef] [PubMed]

118. Aiken, L.S.; Stephen, W. Multiple Regression: Testing and Interpreting Interactions; Sage Publications: Thousand Oaks, CA, USA, 1991.

119. Campbell, J.L. Why would corporations behave in socially responsible ways? An institutional theory of corporate social responsibility. Acad. Manag. Rev. 2007, 32, 946-967. [CrossRef]

(C) 2017 by the authors. Licensee MDPI, Basel, Switzerland. This article is an open access article distributed under the terms and conditions of the Creative Commons Attribution (CC BY) license (http://creativecommons.org/licenses/by/4.0/). 